\title{
RESPONS PERTUMBUHAN DAN HASIL BEBERAPA VARIETAS TANAMAN JAGUNG (Zea mays L.) TERHADAP SISTEM TUMPANGSARI DENGAN TANAMAN UBIKAYU (Manihot esculenta Crantz)
}

\author{
Sandi Suseno, Muhammad Kamal \& Sunyoto \\ Jurusan Agroteknologi, Fakultas Pertanian Universitas Lampung \\ J1. Prof. Soemantri Brodjonegoro, No. 1, Bandar Lampung 35145 \\ E-mail: mshandyc@ymail.com \\ *Korespondensi e-mail : Mkamal1961@yahoo.com. Telp. 08127933781
}

\begin{abstract}
ABSTRAK
Pengembangan jagung secara monokultur menghadapi kendala kompetisi penggunaan lahan dengan tanaman pangan lainnya. Salah satu cara mengatasi hal tersebut adalah dengan melakukan sistem tumpangsari. Penelitian ini bertujuan untuk mengetahui pertumbuhan dan hasil tanaman jagung pada sistem tumpangsari dengan ubikayu dan sistem monokultur dan untuk mengetahui pengaruh varietas terhadap pertumbuhan dan hasil tanaman jagung yang ditumpangsarikan dengan tanaman ubikayu. Penelitian ini dilaksanakan di Kebun Percobaan Badan Penelitian Tanaman Pangan (BPTP) Natar, Kecamatan Rajabasa, Kabupaten Lampung Selatan dan Laboratorium Agronomi, Fakultas Pertanian, Universitas Lampung pada bulan November 2012 sampai dengan Maret 2013. Perlakuan disusun secara faktorial dengan petak terbagi dalam Rancangan Acak Kelompok (RAK) dengan 3 ulangan . Petak utama adalah pola pertanaman, yaitu monokultur dan tumpangsari, Anak petak adalah varietas tanaman jagung yang terdiri dari lima varietas yaitu P27, DK77, DK85, DK95, NK22. Petak percobaan yang digunakan pada penelitian ini berukuran 4 x 3,2 m. Data di analisis dengan ANOVA. Perbedaan nilai tengah perlakuan ditentukan dengan uji BNJ pada taraf 5\%. Hasil penelitian menunjukkan Respons pertumbuhan dan hasil tanaman jagung terhadap sistem tumpangsari dengan ubikayu tidak tergantung pada varietas jagung. Pertumbuhan jagung pada sistem tumpangsari dan monokultur juga relatif sama. Pada sistem monokultur bobot biji kering per tanaman 15\% lebih tinggi dari pada sistem tumpangsari. Antar - varietas, NK22 memiliki bobot biji kering per tanaman tertinggi, yaitu masing masing 4,7\%;8,8\%; 10,2\%, dan 11,1\% lebih tinggi dibandingkan dengan DK77, DK95, P27 dan DK85.
\end{abstract}

Kata kunci : monokultur, tumpangsari, varietas jagung, pola pertanaman.

\section{PENDAHULUAN}

Jagung (Zea mays L.) merupakan salah satu tanaman pangan penting di Indonesia. Selain sebagai sumber karbohidrat, jagung juga dimanfaatkan sebagai pakan ternak (hijauan maupun tongkolnya), diambil minyaknya (dari bulir), dibuat tepung (dari bulir, dikenal dengan istilah tepung jagung atau maizena), dan bahan baku industri (Tim Karya Tani Mandiri, 2010).

Berdasarkan data Badan Pusat Statistik (BPS) dan Dirjen Tanaman Pangan Kementerian Pertanian (Kementan), produksi jagung nasional mencapai 17,6 juta ton pipilan kering dengan luas panen 4,8 juta hektar (ha). Kebutuhan jagung untuk pakan ternak meningkat dari 6 juta ton pada 2011 menjadi 6,75 juta ton. Perkiraan total konsumsi pakan ternak sebesar 13,5 juta ton yang terdiri dari 12,3 juta ton pakan ternak dan 1,2 juta ton pakan ikan (BPS dan Kementan, 2012).

Tanaman jagung umumnya dilbudidayakan pada lahan kering yang baik secara monokultur maupun tumpang sari. Pada sistem tumpang sari, faktor penting yang harus diperhatikan adalah pengaturan waktu tanam, jarak tanam, dan jenis tanaman yang akan ditumpangsarikan. Hali ini bertujuan untuk meminimalkan terjadinya persaingan hara dan cahaya antar tanaman yang ditumpangsarikan. Komoditas yang dapat dipilih untuk tumpang sari dengan tanaman jagung antara lain kacang tanah, kedelai, kacang hijau atau ubi kayu (singkong) (Tim Karya Tani Mandiri, 2010). Kamal (2010) juga menyatakan bahwa pengembangan sistem tumpangsari dapat meningkatkan efisiensi pemanfaatan cahaya persatuan luas lahan.

Tanaman ubikayu di Indonesia umumnya dibudidayakan pada lahan kering seperti di Lampung dan Jawa. Pertumbuhan tanaman ubikayu juga umumnya sangat lambat selama 3 bulan pertama yang menyebabkan tanah diantara tanaman tidak tertutup secara sempurna oleh kanopi. Hal ini menyebabkan tingginya intensitas cahaya matahari diantara tanaman sehingga memacu pertumbuhan gulma (Richana, 2012). Kamal (2011) juga melaporkan bahwa pada fase awal pertumbuhan ubikayu ruang tumbuh antar barisan ubikayu masih cukup tersedia, sehingga bisa ditanami tanaman palawija seperti jagung, kacang tanah dan 
sorgum. Selain itu, umumnya tanaman ubikayu diusahakan pada lahan kering. Tanah di daerah lahan kering sangat rentan terhadap erosi. Daerah lahan kering biasanya mempunyai curah hujan yg rendah dan intensitas yang rendah pula, dengan kondisi seperti itu menyebabkan susahnya tanaman tumbuh dan berkembang, padahal tanaman merupakan media penghambat agar butiran hujan tidak berbentur langsung dengan tanah. Benturan seperti inilah yg menyebabkan tanah mudah terurai sehingga gampang di bawa oleh aliran air permukaan dan akhirnya terjadi erosi. Pemanfaatan vegetasi pada sistem konservasi tanah dan air selain sebagai penghambat benturan juga berguna sebagai penghambat aliran permukaan, memperbaiki tekstur tanah dan meningkatkan kadar air tanah (Agrica, 2007).

Wargiono (2011) dalam Richana (2012), melaporkan hasil umbi varietas Adira-4 yang ditumpang sarikan dengan kacang tanah dan jagung di Bogor dan di Lampung masing masing mencapai 31,0 ton $\mathrm{ha}^{-1}$ dan 39,2 ton/ha. Pengembangan sistem tumpangsari dengan ubikayu dapat membantu dalam upaya mengatasi kendala kompetisi penggunaan lahan (Herawati $d k k$., 2012), khususnya pada wilayah lahan kering yang didominasi pertanian oleh tanaman ubikayu. Menurut (BPS, 2012) luas panen pertanaman ubikayu di provinsi lampung mencapai 314.917 ha sementara total luas panen ubikayu diindonesia 1.119 .784 ha.

Namun dalam hal ini hanya memaparkan produktifitas ubikayu, sedangkan informasi tentang tanaman jagung pada sistem tumpangsari dengan ubikayu tidak dilaporkan secara rinci. Dengan demikian perbandingan tanaman jagung pada sistem tumpangsari dengan ubikayu dan secara monokultur dijelaskan secara lengkap. Singkatnya, informasi agronomi tentang tanaman jagung yang ditumpangsarikan dengan ubikayu masih sedikit dilaporkan. Adapun tujuan dari penelitian ini adalah untuk mengetahui pertumbuhan dan hasil tanaman jagung pada sistem tumpangsari dengan ubikayu dan sistem monokultur dan untuk mengetahui pengaruh varietas terhadap pertumbuhan dan hasil tanaman jagung yang ditumpangsarikan dengan tanaman ubikayu.

\section{BAHAN DAN METODE}

Penelitian ini dilaksanakan di Kebun Percobaan Balai Pengkajian Teknologi Pertanian (BPTP), Provinsi Lampung dan Laboratorium Agronomi, Fakultas Pertanian, Universitas Lampung pada bulan November 2012 sampai Maret 2013. Bahan yang digunakan adalah bibit ubikayu varietas Kasetsat siap tanam dan benih jagung hibrida yang terdiri dari 5 varietas yaitu P27, DK 77, DK 85, DK 95, NK 22. Alat yang digunakan dalam penelitian ini adalah tali raffia, bambu, meteran, alat semprot atau gembor, cangkul, timbangan, kamera, jangka sorong, klorofilmeter dan alat tulis.

Perlakuan disusun secara faktorial dengan petak terbagi dalam Rancangan Acak Kelompok (RAK) dengan 3 ulangan. Petak utama adalah pola pertanaman, yaitu monokultur dan tumpangsari, anak petak adalah varietas tanaman jagung yang terdiri dari lima varietas yaitu P27, DK 77, DK 85, DK 95, NK 22. Petak percobaan yang digunakan pada penelitian ini berukuran 4 x 3,2 m, data di analisis dengan ANOVA. Perbedaan nilai tengah perlakuan ditentukan dengan uji BNJ pada taraf 5\%.

Pelaksanaan dalam penelitian ini meliputi persiapan penelitian dan tata letak percobaan, pengolahan tanah, penanaman, pengamatan yaitu pada komponen pertumbuhan (tinggi tanaman, diameter batang, jumlah daun, tingkat kehijauan daun) dan komponen hasil (bobot tongkol kering per tanaman, diameter tongkol, panjang tongkol, jumlah biji per tanaman, bobot biji per tanaman, dan bobot 100 butir.

\section{HASIL DAN PEMBAHASAN}

Hasil dari analisis ragam tentang pengaruh pola pertanaman, varietas dan interaksinya terhadap pertumbuhan dan hasil tanaman jagung (Zea mays L.) dapat dilihat pada (Tabel 1).

Hasil penelitian menunjukkan bahwa, interaksi perlakuan hanya terdapat pada tinggi tanaman jagung 2 mst dan jumlah daun 2 mst, sedangkan pola pertanaman berpengaruh nyata pada tinggi tanaman 6 dan $8 \mathrm{mst}$, diameter batang $8 \mathrm{mst}$, tingkat kehijauan daun 8 dan 10 mst, bobot tongkol + kelobot kering per tanaman, bobot tongkol kering per tanaman, bobot biji per tanaman, bobot 100 butir dan hari keluar tongkol, sedangkan varietas berpengaruh nyata pada tinggi tanaman 2, 4, 6, 8 dan 10 mst, jumlah daun 2, 4, 6, dan 10 mst, diameter batang 4 , 6, 8 dan 10 mst, tingkat kehijauan daun 8 dan 10 mst, panjang tongkol, jumlah biji per tanaman, bobot biji per tanaman, dan bobot 100 butir.

Dari hasil penelitian respons pertumbuhan dan hasil tanaman jagung (Zea mays. L) pada sistem tumpangsari dengan tanaman ubikayu (Manihot esculenta Crantz) menunjukkan bahwa sebagian besar tidak terdapat interaksi yang nyata antara pola pertanaman dan varietas tanaman jagung pada komponen pertumbuhan maupun komponen hasil (Tabel 1). Interaksi antara pola pertanaman dan varietas tanaman jagung pada penelitian ini hanya ditunjukkan pada 
Tabel 1. Signifikasi pengaruh pola pertanaman, varietas jagung dan interaksinya terhadap variabel pertumbuhan dan hasil tanaman jagung.

\begin{tabular}{|c|c|c|c|}
\hline Pengamatan & Pola Pertanaman & Varietas & Interaksi \\
\hline Tinggi tanaman (2 mst) & $\operatorname{tn}$ & $*$ & $*$ \\
\hline Ting gi tanaman (4 mst) & tn & $*$ & tn \\
\hline Tinggi tanaman (6 mst) & $*$ & $*$ & $\operatorname{tn}$ \\
\hline Ting gi tanaman ( $8 \mathrm{mst})$ & $*$ & $*$ & tn \\
\hline Tinggi tanaman $(10 \mathrm{mst})$ & tn & $*$ & tn \\
\hline Jumlah daun (2 mst) & $\operatorname{tn}$ & tn & $*$ \\
\hline Jumlah daun (4 mst) & $\operatorname{tn}$ & $*$ & $\operatorname{tn}$ \\
\hline Jumlah daun (6 mst) & tn & $*$ & tn \\
\hline Jumlah daun (8 mst) & tn & $*$ & tn \\
\hline Jumlah daun (10 mst) & $\operatorname{tn}$ & $*$ & $\operatorname{tn}$ \\
\hline Diameter batang (4 mst) & $\operatorname{tn}$ & $*$ & tn \\
\hline Diameter batang ( $6 \mathrm{mst})$ & tn & $*$ & tn \\
\hline Diameter batang ( $8 \mathrm{mst})$ & $*$ & $*$ & tn \\
\hline Diameter batang $(10 \mathrm{mst})$ & tn & $*$ & tn \\
\hline Tingkat kehijauan daun (4 mst) & $\operatorname{tn}$ & tn & tn \\
\hline Tingkat kehijauan daun ( 8 mst) & $*$ & $*$ & tn \\
\hline Tingkat kehijauan daun (10 mst) & $*$ & $*$ & tn \\
\hline Bobot Tongkol+Kelobot Kering/Tan aman & $*$ & tn & tn \\
\hline Bobot Tongkol Kering/Tanaman & $*$ & tn & $\operatorname{tn}$ \\
\hline Diameter Tongkol & tn & tn & tn \\
\hline Panjang Tongkol & tn & $*$ & tn \\
\hline Jumlah Biji/Tanaman & $\operatorname{tn}$ & $*$ & $\operatorname{tn}$ \\
\hline Bobot Biji/Tanaman & $*$ & * & tn \\
\hline Bobot 100 Butir & $*$ & $*$ & tn \\
\hline Hari Keluar Tongkol & $*$ & tn & tn \\
\hline
\end{tabular}

Keterangan: * = berbeda nyata dan tn $=$ tidak berbeda nyata menurut uji BNJ pada $\alpha_{0,05}$.

variabel tinggi tanaman 2 mst dan jumlah daun 2 mst, hal ini dikarenakan faktor lingkungan. Menurut Kamal (2011), Produksi tanaman pangan pada dasarnya dapat dipandang sebagai hasil dari suatu proses interaksi antara tanaman dan lingkungannya, sehingga kondusifitas lingkungan tumbuh dapat mengoptimalkan produksi tanaman sesuai potensi genetiknya. Dalam proses pertumbuhan dan produksinya, tanaman memanfaatkan sumberdaya yang ada disekitarnya atau faktor lingkungan. Faktor ini terdiri dari cahaya, air, udara, unsur hara dan media tumbuh.

Pada komponen pertumbuhan tanaman jagung umumnya tidak terdapat interaksi antara pola pertumbuhan dan varietas tanaman jagung namun hanya dipengaruhi faktor tunggal saja. Pada sistem monokultur memiliki nilai yang lebih tinggi dibandingkan dengan sistem tumpangsari untuk variabel tinggi tanaman, jumlah daun dan diameter batang. Pola tanam monokultur memiliki pertumbuhan dan hasil yang lebih besar daripada pola tanam lainnya. Hal ini disebabkan karena sedikitnya persaingan antar tanaman dalam memperebutkan unsur hara maupun sinar matahari.

Pada tingkat kehijauan daun, sistem tumpangsari memiliki nilai yang lebih tinggi dibandingkan dengan sistem monokultur walaupun pada 4 mst memiliki nilai yang sama namun pada 8 dan $10 \mathrm{mst}$ sistem tumpangsari memiliki nilai yang lebih tinggi dibandingkan dengan sistem monokultur. Hal ini dikarenakan tanaman jagung pada sistem tumpangsari memiliki tinggi tanaman yang kebih tinggi dari pada ubikayu sehingga sinar matahari sebagian besar diserap oleh tanaman jagung.

Pada komponen pertumbuhan, varietas NK22 memiliki tinggi tanaman, jumlah daun, diameter batang dan tingkat kehijauan daun yang lebih baik dibandingkan dengan varietas DK95, DK85, DK77 dan P27. Pada komponen hasil juga, umumnya tidak terdapat interaksi 
Tabel 2. Pengaruh pola pertanaman dan varietas terhadap komponen hasil tanaman jagung.

\begin{tabular}{lcccccccc}
\hline \multirow{2}{*}{ Perlakuan } & \multicolumn{7}{c}{ Komponen Hasil } \\
\cline { 2 - 9 } & BTK $(\mathrm{g})$ & BT $(\mathrm{g})$ & DT $(\mathrm{cm})$ & PT $(\mathrm{cm})$ & JPT (biji) & BB $(\mathrm{g})$ & B100 (g) & HKT (hari) \\
\hline Pola Pertanaman & & & & & & & & \\
Monokultur & $198,49 \mathrm{a}$ & $185,40 \mathrm{a}$ & $4,13 \mathrm{a}$ & $12,89 \mathrm{a}$ & $372,67 \mathrm{a}$ & $121,03 \mathrm{a}$ & $41,11 \mathrm{a}$ & $56,87 \mathrm{~b}$ \\
Tumpangsari & $186,37 \mathrm{~b}$ & $174,88 \mathrm{~b}$ & $4,08 \mathrm{a}$ & $12,13 \mathrm{a}$ & $363,27 \mathrm{a}$ & $102,91 \mathrm{~b}$ & $39,41 \mathrm{~b}$ & $59,40 \mathrm{a}$ \\
Varietas & & & & & & & & \\
P27 & $188,38 \mathrm{a}$ & $176,82 \mathrm{a}$ & $4,07 \mathrm{a}$ & $11,62 \mathrm{~b}$ & $356,33 \mathrm{~b}$ & $107,08 \mathrm{~b}$ & $38,37 \mathrm{~b}$ & $58,17 \mathrm{a}$ \\
DK77 & $190,30 \mathrm{a}$ & $178,15 \mathrm{a}$ & $4,07 \mathrm{a}$ & $11,28 \mathrm{~b}$ & $367,00 \mathrm{ab}$ & $111,62 \mathrm{ab}$ & $38,78 \mathrm{~b}$ & $58,00 \mathrm{a}$ \\
DK85 & $187,73 \mathrm{a}$ & $175,33 \mathrm{a}$ & $4,03 \mathrm{a}$ & $12,53 \mathrm{ab}$ & $360,33 \mathrm{~b}$ & $107,02 \mathrm{~b}$ & $39,83 \mathrm{~b}$ & $58,83 \mathrm{a}$ \\
DK95 & $191,88 \mathrm{a}$ & $179,37 \mathrm{a}$ & $4,15 \mathrm{a}$ & $13,12 \mathrm{ab}$ & $370,00 \mathrm{ab}$ & $109,42 \mathrm{~b}$ & $41,15 \mathrm{ab}$ & $57,83 \mathrm{a}$ \\
NK22 & $203,85 \mathrm{a}$ & $191,03 \mathrm{a}$ & $4,20 \mathrm{a}$ & $13,98 \mathrm{a}$ & $386,17 \mathrm{a}$ & $124,72 \mathrm{a}$ & $43,17 \mathrm{a}$ & $57,83 \mathrm{a}$ \\
\hline
\end{tabular}

Keterangan: Angka yang diikuti huruf yang sama pada kolom dan perlakuan yang sama berbeda tidak nyata menurut uji BNJ pada $\alpha_{0,05}$. BTK = bobot tongkol+kelobot kering per tanaman, BT = bobot tongkol kering per tanaman, DT = diameter tongkol, $\mathrm{PT}=$ panjang tongkol, JPT $=$ jumlah biji per tanaman, $\mathrm{BB}=$ bobot biji per tanaman, $\mathrm{B} 100=$ bobot 100 butir, dan HKT $=$ hari keluar tongkol.

antara pola pertanaman dan varietas tanaman jagung namun hanya dipengaruhi faktor tunggal saja. Pada komponen hasil bobot tongkol+kelobot kering per tanaman, bobot tongkol kering per tanaman, bobot biji per tanaman, bobot 100 butir dan hari keluar tongkol terdapat perbedaan huruf mutu yang mana pada sistem monokultur lebih baik pada sistem tumpangsari. Menurut Warsana (2009), pada sistem tumpangsari sebaran sinar matahari merupakan hal yang sangat penting. Hal ini bertujuan untuk menghindari persiangan antar tanaman yang ditumpangsarikan dalam hal mendapatkan sinar matahari, selain itu perlu diperhatikan juga tinggi dan luas antar tajuk tanaman yang ditumpangsarikan. Tinggi dan lebar tajuk antar tanaman yang ditumpangsarikan akan berpengaruh terhadap penerimaan cahaya matahari, dan lebih lanjut akan mempengaruhi hasil sintesa (glukosa) dan muara terakhir akan berpengaruh terhadap hasil secara keseluruhan.

Berdasarkan dari penjelasan diatas juga dapat diketahui bahwa bobot tongkol+kelobot kering per tanaman dapat mempengaruhi bobot tongkol kering per tanaman, bobot biji per tanaman dan bobot 100 butir. Sedangkan pada diameter tongkol, panjang tongkol dan jumlah biji per tanaman lebih dipengaruhi oleh faktor genetik dari masing masing varietas jagung, hal ini dibuktikan pada faktor tunggal yaitu pada pola pertanaman tidak memiliki huruf mutu yang berbeda walaupun memiliki nilai statistik yang berbeda.

Menurut hasil penelitian Suwarto $d k k$. (2005), Tanaman ubikayu dalam tumpang sari meningkatkan kompetisi intraspesies tanaman jagung varietas Arjuna, Pioner 4, dan Cargill 9 sehingga bobot kering biji yang dihasilkan menurun, masing-masing menurun 9.7, 6.7, dan 16.9 persen dari pertanaman monokultur. Sistem tumpang sari tetap mampu meningkatkan produktivitas lahan walaupun terjadi penurunan hasil masing-masing komoditas akibat kompetisi. Tumpang sari ubikayu dengan jagung varietas Arjuna, Pioner 4, dan Cargill 9 dengan berbagai tingkat populasi; seluruhnya menghasilkan nisbah kesetaraan lahan lebih dari 1.0.

Hasil penelitian menunjukkan sistem monokultur bobot biji kering per tanaman $15 \%$ lebih tinggi dari pada sistem tumpangsari. Antar varietas, NK22 memiliki bobot biji kering per tanaman tertinggi, yaitu masing masing $4,7 \% ; 8,8 \% ; 10,2 \%$ dan $11,1 \%$ lebih tinggi dibandingkan dengan DK77, DK95, P27 dan DK85. Tampaknya perbedaan bobot biji kering per tanaman merupakan faktor penting yang mendasari perbedaan bobot biji pertanaman.

\section{KESIMPULAN}

Respons pertumbuhan dan hasil tanaman jagung terhadap sistem tumpangsari dengan ubikayu tidak tergantung pada varietas jagung. Pertumbuhan jagung pada sistem tumpangsari dan monokultur juga relatif sama. Pada sistem monokultur bobot biji kering per tanaman $15 \%$ lebih tinggi dari pada sistem tumpangsari. Antar - varietas, NK22 memiliki bobot biji kering per tanaman tertinggi, yaitu masing masing $4,7 \% ; 8,8 \%$; $10,2 \%$, dan $11,1 \%$ lebih tinggi dibandingkan dengan DK77, DK95, P27 dan DK85. Tampaknya perbedaan bobot biji kering per tanaman merupakan faktor penting yang mendasari perbedaan bobot biji pertanaman. 


\section{SANWACANA}

Penulis mengucapkan terima kasih kepada Dr. Ir. Agus Karyanto, M.Sc. atas bimbingan selama penulis malakukan penelitian.

\section{DAFTAR PUSTAKA}

Agrica. 2007. Bensin Singkong. Lembaga Pers Mahasiswa AGRICA Fakultas Pertanian Unsoed Purwokerto, Edisi XIX/Tahun XXI.

Departemen Pertanian. 2012. Badan Pusat Statistik dan Direktorat Jenderal Tanaman Pangan. www.deptan.go.id. 2012.

Hamim, H., R. Larasati. dan M. Kamal. 2012. Analisis komponen hasil sorgum (Sorghum bicolor (L.) Moench) yang ditanam tumpangsari dengan ubikayu dan waktu tanam berbeda. Prosiding Simposium dan Seminar Bersama PERAGIPERHORTI-PERIPI-HIGI. HIm 91-94.

Juhriah dan M. Alam. 2012. Kekerabatan plasma nuftah jagung lokal Sulawesi Utara dan Gorontalo dengan jagung provitamin asal CMMYT berdasarkan karakter morfologi. Prosiding Simposium dan Seminar Bersama PERAGIPERHORTI-PERIPI-HIGI. HIm 291-295.
Kamal, M. 2011. Kajian Sinergi Pemanfaatan Cahaya dan Nitrogen dalam Produksi Tanaman Pangan. Pidato ilmiah pengukuhan guru besar ilmu tanaman pada 23 Februari 2011. Penerbit Universitas Lampung.

Pujisiswanto, H. 2003. Analisis pertumbuhan gulma, tanaman dan hasil tumpangsari jagung manis dengan berbagai populasi tiga varietas kacang hijau. Tesis. Fakultas Pertanian. UGM. 122hlm.

Richana, N. 2012. Ubi Kayu dan Ubi Jalar. Penerbit Nuansa. Bandung. $122 \mathrm{hlm}$.

Suwarto., S. Yahya. Handoko. dan M. A. Chozin. 2005. Kompetisi tanaman jagung dan ubikayu dalam sistem tumpangsari. Bul. Agron. 33 (2): 1-7.

Tim Karya Tani Mandiri. 2010. Pedoman Bertanam Jagung. CV Nuansa Aulia. Bandung. 208 hlm.

Warsana. 2009. Introduksi Teknologi Tumpangsari Jagung dan Kacang Tanah. Tabloid Sinar Tani. 25 Pebruari 2009. Jawa Tengah. 